\title{
Die-offs of the endangered pearl mussel Margaritifera margaritifera during an extreme drought
}

\author{
Ronaldo Sousa $^{1}$ (D) | André Ferreira ${ }^{1}$ | Francisco Carvalho ${ }^{1}$ | Manuel Lopes-Lima ${ }^{2}$ (D) । \\ Simone Varandas ${ }^{3}$ | Amílcar Teixeira ${ }^{4}$
}

${ }^{1}$ CBMA, Department of Biology, University of Minho, Braga, Portugal

${ }^{2} \mathrm{CIBIO} / \mathrm{InBIO}$, University of Porto, Vairão, Portugal

${ }^{3}$ CITAB-UTAD, University of Trás-os-Montes and Alto Douro, Vila Real, Portugal

${ }^{4}$ CIMO-ESA-IPB, School of Agriculture, Polytechnic Institute of Bragança, Bragança, Portugal

\section{Correspondence}

Ronaldo Sousa, CBMA - Centre of Molecular and Environmental Biology, Department of Biology, University of Minho, Campus Gualtar, 4710-057 Braga, Portugal

Email: rg.eco.sousa@gmail.com

\section{Funding information}

Foundation for Science and Technology (FCT), Grant/Award Numbers: PTDC/AGR-FOR/ 1627/2014, 3599 and SFRH/BD/115728/ 2016

\section{Abstract}

1. Droughts may be responsible for important ecological impacts in freshwater ecosystems, including the death of rare species.

2. This study assessed the mortality of the endangered pearl mussel Margaritifera margaritifera (Linnaeus, 1758) in the Mente, Rabaçal and Tuela rivers (north west of the Iberian Peninsula) during the extreme summer drought of 2017.

3. Mortality occurred as a result of the low river flow, which led to mussel stranding near the banks and consumption (by predation or scavenging) by wild boar Sus scrofa (Linnaeus, 1758).

4. Mortality differed across sites. The shell lengths of live mussels (measured before the drought) and dead mussels significantly differed in the Rabaçal River, but not in the Mente and Tuela rivers.

5. Extreme droughts are predicted to increase in number and intensity in the future, and possible impacts on rare species such as $M$. margaritifera should be carefully monitored. Several M. margaritifera populations in Iberia (and elsewhere) may now be at increased risk, and measures should be implemented in order to mitigate the impacts of future extreme droughts.

\section{KEYWORDS}

conservation, extreme climatic events, freshwater mussel, Iberia, wild boar

\section{1 | INTRODUCTION}

The number and intensity of extreme climatic events are predicted to increase in response to climate change (Intergovernmental Panel on Climate Change, IPCC, 2014), and some studies (Ciais et al., 2005; Garrabou et al., 2009; Gilmour, Smith, Heyward, Baird, \& Pratchett, 2013; Kemp et al., 2011; Wernberg et al., 2016) have already described the ecological and economic impacts generated by droughts, floods, heatwaves, and cold fronts in terrestrial and aquatic ecosystems.

Droughts in freshwater ecosystems are considered a natural disturbance (often exacerbated by water withdrawals for human use) that may have important ecological and economic effects (Lake, 2011). Rivers are now drying out more frequently, and this may affect biodiversity (Cayan et al., 2010; Gleick, 2003; Lake, 2011). However, detailed quantitative studies about die-offs caused by droughts at the population level are rare, but they do include some examples on freshwater bivalves: Bódis, Tóth, and Sousa (2014); Golladay, Gagnon, Kearns, Battle, and Hicks (2004); Mouthon and Daufresne (2006, 2015).

The freshwater pearl mussel Margaritifera margaritifera (Linnaeus, 1758 ) is globally classified as an endangered species by the International Union for Conservation of Nature (IUCN), and its distribution includes Europe (from Portugal to Russia) and North America (along the north-east coast of the USA and Canada) (Geist, 2010). This species mainly colonizes rivers with oligotrophic conditions, and has been suffering severe declines in abundance and distribution in recent 
decades owing to increased pollution, habitat loss and fragmentation, overexploitation, climate change, and the introduction of invasive species (reviewed in Geist, 2010). Margaritifera margaritifera has been subjected to many management plans in Europe (and many are still continuing) aiming to preserve or restore their favourable conservation status (Gum, Lange, \& Geist, 2011; Lopes-Lima et al., 2017). In Portugal, this species has been studied extensively, focusing mainly on its distribution, abundance, and threats, with the species having been described in the Neiva, Cávado, Terva, Beça, Paiva, Mente, Rabaçal, and Tuela rivers (Reis, 2003; Santos et al., 2015; Sousa et al., 2013; Varandas et al., 2013). The main threats described above (with the exception of overexploitation, which was apparently never a problem in Iberia) are also valid for Iberian populations. However, a recent study showed that these southern populations may be highly susceptible to climate change, as future projections of precipitation revealed that pearl mussels could be at risk because of the expected decrease in river flow (Santos et al., 2015).

The aims of this study were to report a massive die-off of $M$. margaritifera in the Mente, Rabaçal, and Tuela rivers, and to discuss briefly the conservation implications. We hypothesize that droughts can be responsible for significant die-offs of $M$. margaritifera, but this situation will vary spatially. We also hypothesize that no differences in average shell length will be found in the comparison of live animals measured before the drought and dead organisms found after the drought. The results reported here provide a first indication of the potential effects of reduced river flows on the survival of an endangered invertebrate species that, given the paucity of research on this topic, needs more conservation attention.

\section{2 | MATERIALS AND METHODS}

\section{1 | Study area}

The Mente, Rabaçal, and Tuela rivers, all located in the north west of the Iberian Peninsula (Figure 1a), are tributaries of the Tua River in the Douro basin. The Mente River has a length of $57 \mathrm{~km}$, the Rabaçal River has a length of $88 \mathrm{~km}$, and the Tuela River has a length of $102 \mathrm{~km}$. All rivers experience a similar climate, with precipitation having high seasonal and interannual variability (Oliveira et al., 2012). Floods may occur during winter or early spring, with a gradual decrease in river flow that reaches minimum values in late summer or early autumn. These three rivers have a high conservation value owing to low human density and thereby low human pressure, and still retain important habitats for threatened species (Oliveira et al., 2012; Sousa et al., 2015).

\subsection{Sampling and data analysis}

Data on precipitation since 1980 were compiled using the nearby Rio Torto meteorological station (located $15 \mathrm{~km}$ south of site R1, Figure 1a). This information was used as a proxy for river flow (Magalhães, Beja, Schlosser, \& Collares-Pereira, 2007), as there are no data on this parameter for the three study rivers.

The impact of the 2017 drought and consequent assessment of the die-off of pearl mussels coincided with a detailed investigation of the possible effects of small dams on pearl mussel populations in the Mente, Rabaçal, and Tuela rivers. Corresponding mussel abundances were recorded at 66 sites (Figure 1a) 3 weeks before the die-off (i.e. from the end of July to early August 2017). At each site, the presence of pearl mussels was investigated by snorkelling for periods of $5 \mathrm{~min}$, repeated between four and nine times by three or four different divers. At each site a 50-m stretch of river was surveyed, covering all microhabitat types (including the banks and the central part of the channel, as well as riffle and pool areas; Cummings, Jones, \& Lopes-Lima, 2016). Abundance was assessed as the number of individuals (catch per unit effort, CPUE) during 5-min sampling periods. The number of replicates was different at each site, with more time spent at sites with lower abundances. Every live mussel was counted and its length measured (to $0.1 \mathrm{~mm}$ ) with a digital calliper. After the measurements, all individuals were immediately returned to their original position. (a)

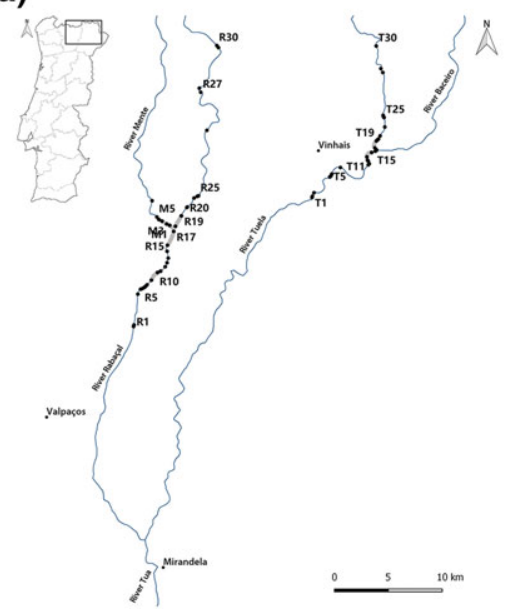

(b)

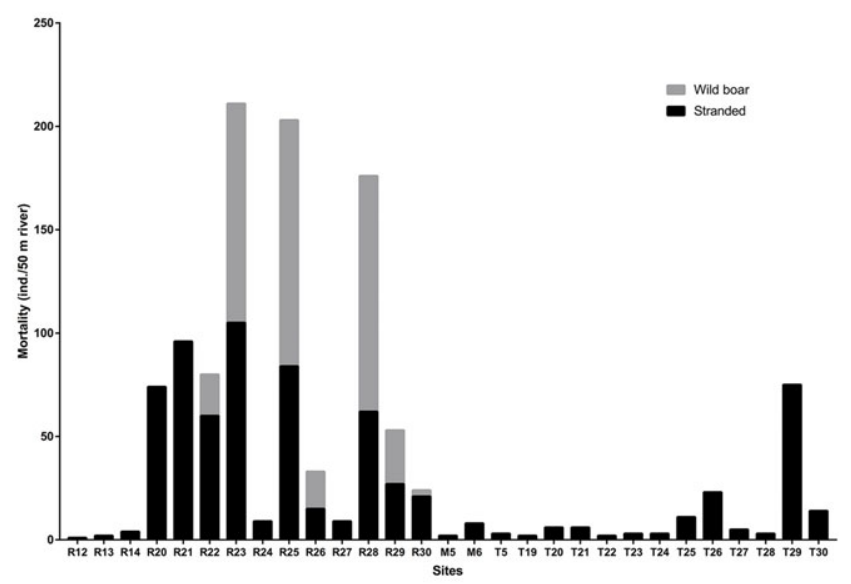

FIGURE 1 Map of the study area, showing the 66 surveyed sites on the Mente, Rabaçal, and Tuela rivers (a), and the number of dead Margaritifera margaritifera individuals per site found stranded or with marks of wild boar consumption (b); only sites where mortality was found are represented 
In mid-August 2017, as a result of the rapid decrease in river flow and water depth, dead mussels were found stranded along the banks, but not in the centre of the channel. The 66 sampling sites were revisited, therefore, on 21-23 August, 28-30 August, 28-30 September, and 18-20 October 2017, searching for dead mussels in both river banks along the 50-m stretch of river. All dead mussels were counted and their length measured as mentioned above. At some sites, shell fragments were also retrieved, most of them showing marks of predation or scavenging. Only fragments in which the umbo was found were considered for the study. A relationship between the length of the hinge and the total length was established (data not shown) in order to assess the total length of mussels that had been exposed to predation or scavenging. Mann-Whitney tests were used to check for possible differences in the average shell length between live and dead organisms in each river.

\section{3 | RESULTS}

The 2017 drought in Portugal, and particularly in the three rivers studied, started in March and reached its maximum severity between August and October. The Palmer Drought Severity Index during October 2017 showed that $75.2 \%$ of the territory experienced extreme drought (including the three river basins studied), and that 24.8\% experienced severe drought (Instituto Português do Mar e da Atmosfera, IPMA, 2017). The cumulative precipitation recorded at the Rio Torto meteorological station for the meteorological year 2016/17 (from October 2016 to September 2017) showed much lower values $(345 \mathrm{~mm})$ than the average recorded since 1980 (555 mm). The reduced precipitation was responsible for a rapid decrease in flow in the three surveyed rivers, mainly after the middle of August. Although none of the rivers dried out completely in any stretch, a considerable drop in water level was observed, and areas with lower depths near the banks dried out completely by the end of August (Figure S1A, C, and D).

Live individuals sampled before the die-offs were found in 41 of the 66 sites, and abundance varied between 0 individuals (CPUE), at sites R6, R8-R11, R15, R17-R19, M1-M3, T2, T3, T6, T7, T9-T14, and T16-T19, and 107 individuals (CPUE) at site R25. The 25 sites with no individuals were found in areas located in reservoirs or immediately downstream.

In total, 1141 dead M. margaritifera were collected at 29 of the 66 sites, comprising 735 individuals (64.4\%) found stranded mainly near the banks (Figure S1B) and 406 individuals (35.6\%) that had marks of consumption by the wild boar Sus scrofa (Linnaeus, 1758) (Figure S1E and F). Most of the stranded individuals were found with the paired valves in situ, indicating that the pearl mussels had died in place in the substrate (Figure S1B). It was impossible to distinguish between mussels that had been preyed upon and those that had been scavenged, but because most of the shell fragments were found under water and contained fresh soft material it is likely that many animals had suffered predation.

The total numbers of dead mussels (stranded plus those consumed by wild boars) collected at each sampling time were: 392 from 21 to 23 August; 311 from 28 to 30 August; 308 from 28 to 30
September; and 130 from 18 to 20 October. The number of dead mussels per site varied considerably, with particularly large numbers recorded at sites R23, R25, and R28, all located in the Rabaçal River (Figure 1b). A positive relationship was established between the abundance of live specimens collected at the end of July and the beginning of August and the number of dead mussels collected from the end of August to October ( $\left.F=106.80, r^{2}=0.63 ; P<0.001\right)$. Sites with higher abundances of live specimens also had higher mortalities (data not shown). The average shell lengths of live and dead pearl mussels significantly differed in the Rabaçal River (68.8 and $66.4 \mathrm{~mm}$ for live and dead mussels, respectively; $P=0.007$ ), but not in the Mente River (73.2 and $72.0 \mathrm{~mm}$ for live and dead mussels, respectively; $P=0.51$ ) or in the Tuela River (72.6 and $71.3 \mathrm{~mm}$ for live and dead mussels, respectively; $P=0.38$ ) (Figure 2 ).

\section{4 | DISCUSSION}

\section{1 | Pearl mussel die-offs}

The 2017 drought was particularly severe in Portugal (IPMA, 2017), including in the Mente, Rabaçal, and Tuela river basins. The meteorological year of 2016/17 had much lower precipitation than the average values recorded at the Rio Torto meteorological station since 1980: only the meteorological year of 2004/05 had a slightly lower precipitation than that recorded for 2016/17.

The rapid decrease in river flow was the most plausible explanation for the recorded die-offs of pearl mussels. The causes of mortality were twofold: (i) desiccation of mussels near the banks when the river level suddenly fell after mid-August (Figure S1B); and (ii) consumption by wild boar (Figure S1E and F). It is not unusual to find dead pearl mussels after droughts or floods in the study area (Sousa et al., 2012), but the numbers reported here are clearly exceptional. Where predation had occurred, we assume that wild boar was the main predator, as there were characteristic tracks seen near the banks and there were distinctive marks left on shells (Figure S1E and F). At three sites (R23, R25, and R28) the number of individuals consumed by wild boars was very high. A similar phenomenon was described in the Negro River (Douro basin, Spain) during the severe drought of 2009 ,

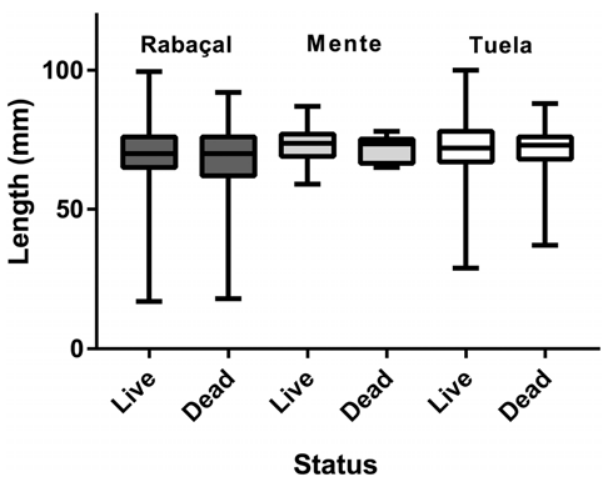

FIGURE 2 Length of live and dead Margaritifera margaritifera in the Rabaçal, Mente, and Tuela rivers. Box plots show average values (central line), the range from the first to the third quartile (box), and minimum and maximum values 
where wild boars were responsible for reducing the abundance of pearl mussels by around $40 \%$ along a $1.5-\mathrm{km}$ stretch of river (Morales, Peñín, \& Lizana, 2011). Other studies (e.g. Walters \& Ford, 2013) have also reported an increase in predation by terrestrial organisms, e.g. Procyon lotor (Linnaeus, 1758), on endangered freshwater mussels during periods of low water levels.

Mortality varied across sites. As expected, sites with a high abundance of live pearl mussels before the drought had generally higher mortalities. In addition to abundance before the drought, other factors such as geomorphology, which governs the availability of refuges, loss of water through evapotranspiration, and water depth (Lake, 2011) were also possibly important in explaining these spatial differences. For example, some sites (e.g. R20, R21, and T29) with intermediate abundances of live animals had high mortalities showing that specific habitat features such as the presence of riffles with very low water depths may also contribute to the differences observed. On the other hand, sites with a high abundance of live animals located in stable and deeper pools (e.g. R27 and T26) had much lower mortalities. Geomorphology was not studied in detail, however, given the rapidity of the die-off, which prevented a full characterization of the habitat features (e.g. water velocity and geomorphology) at the 66 study sites. Previous studies in North American rivers (Golladay et al., 2004; Haag \& Warren, 2008) have reported that mussels located at sites with more stable hydrological conditions and with the presence of refuge areas (deep pools and woody material) were less prone to mortality. The mortality rates of M. margaritifera appear to be context dependent across sites, and include the apparently random effect of wild boar consumption that only occurred at some sites in the Rabaçal River. The shell lengths of dead individuals were marginally smaller than the shell lengths of live specimens measured before the drought, but only in the Rabaçal River were those differences statistically significant. These results suggest that smaller individuals were probably more susceptible to die-offs during droughts.

\section{2 | Implications for conservation}

Extreme droughts are predicted to increase in number and intensity in the future in the study area (Santos et al., 2015). Interestingly, a recent study by Santos et al. (2015) drew attention to the possible effects of climate change (by reduced precipitation) on a pearl mussel population in the Beça River (northern Portugal). The data predict that this pearl mussel population will be on the brink of extinction, owing to the high mortality rates that may occur in areas with low depths and near the banks, which are the preferred habitats for M. margaritifera. Therefore, future extreme droughts may be responsible for massive mortalities at the southern edge of pearl mussel distribution (i.e. in Iberia). Data for the Negro River (Douro basin, Spain) for 2009 have already documented this problem (Morales et al., 2011). The fate of the populations subjected to these extreme climatic events is unknown, and is highly dependent on their recruiting capacity. However, the resistance and resilience of pearl mussels seem to be low, given their immobility (which make this species highly susceptible to emersion), their slow growth rate, their low dispersal capacity, and their complicated life cycle, with the requirement for brown trout, Salmo trutta Linnaeus,
1758 , which is also highly threatened by climate change in the Iberian Peninsula (Almodóvar, Nicola, \& Benigno, 2012), as a host for their larvae.

The Mente, Rabaçal, and Tuela rivers, mainly in the stretches upstream of dams, still support high abundances of pearl mussels. These upstream areas have very low human disturbance and no signs of pollution or other threats (Sousa et al., 2015). If these conditions are maintained, the future impacts resulting from extreme droughts are possibly the main threat to M. margaritifera. This situation needs attention because these three rivers represent the most viable pearl mussel populations in Iberia, and deserve protection (Sousa et al., 2015). The results reported here, as well as by others (Bódis et al., 2014; Golladay et al., 2004; Haag \& Warren, 2008; Mouthon \& Daufresne, 2006, 2015), highlight the adverse effects imposed by severe droughts on freshwater mussels. Mortality from drought could be even worse in future, given the predictions of climate change. With a concomitant increase in water demand for energy and human consumption, the trade-offs between water security for human needs and the conservation of pearl mussel populations and other aquatic organisms will become even more challenging. It is likely, therefore, that these pearl mussel populations will need financially expensive and ecologically risky conservation measures to maintain their favourable conservation status - i.e. monitoring during low water levels, moving pearl mussels subjected to desiccation to adjacent deeper areas or to ex situ facilities, and supplementary stocking with hatchery-raised individuals.

\section{ACKNOWLEDGEMENTS}

This work was supported by Portuguese FCT - Foundation for Science and Technology, Project FRESHCO: Multiple implications of invasive species on Freshwater Mussel co-extinction processes (contract PTDC/AGR-FOR/1627/2014-04/SAICT/2015) and Project 3599Promoting Scientific and Technological Development Production and the Constitution of Thematic Networks (3599-PPCDT), FEDER European Community Funds. FCT also support M.L.L. with a doctoral grant (SFRH/BD/115728/2016). We thank the two anonymous referees for constructive suggestions.

\section{ORCID}

Ronaldo Sousa (D) http://orcid.org/0000-0002-5961-5515

Manuel Lopes-Lima (i) http://orcid.org/0000-0002-2761-7962

\section{REFERENCES}

Almodóvar, G. G., Nicola, D. A., \& Benigno, E. (2012). Global warming threatens the persistence of Mediterranean brown trout. Global Change Biology, 18, 1549-1560.

Bódis, E., Tóth, B., \& Sousa, R. (2014). Massive mortality of invasive bivalves as a potential resource subsidy for the adjacent terrestrial food web. Hydrobiologia, 735, 253-262.

Cayan, D. R., Das, T., Pierce, D. W., Barnett, T. P., Tyree, M., \& Gershunov, A. (2010). Future dryness in the southwest US and the hydrology of the early 21st century drought. Proceedings National Academy of Sciences, 107, 21271-21276.

Ciais, P., Reichstein, M., Viovy, N., Granier, A., Ogée, J., Allard, V., ... Chevallier, F. (2005). Europe-wide reduction in primary productivity caused by the heat and drought in 2003. Nature, 437, 529-533.

Cummings, K. S., Jones, H. A., \& Lopes-Lima, M. (2016). Rapid bioassessment methods for freshwater molluscs. In T. H. Larsen (Ed.), Core 
Standardized Methods for Rapid Biological Field Assessment (pp. 185-207). Arlington, VA: Conservation International.

Garrabou, J., Coma, R., Bensoussan, N., Bally, M., Chevaldonné, P., Cigliano, M., ... Ledoux, J. B. (2009). Mass mortality in Northwestern Mediterranean rocky benthic communities: Effects of the 2003 heat wave. Global Change Biology, 15, 1090-1103.

Geist, J. (2010). Strategies for the conservation of endangered freshwater pearl mussels (Margaritifera margaritifera L.): A synthesis of conservation genetics and ecology. Hydrobiologia, 644, 69-88.

Gilmour, J. P., Smith, L. D., Heyward, A. J., Baird, A. H., \& Pratchett, M. S. (2013). Recovery of an isolated coral reef system following severe disturbance. Science, 340, 69-71.

Gleick, P. H. (2003). Global freshwater resources: Soft-path solutions for the $21^{\text {st }}$ century. Science, 302, 1524-1528.

Golladay, S. W., Gagnon, P., Kearns, M., Battle, J. M., \& Hicks, D. W. (2004) Response of freshwater mussel assemblages (Bivalvia: Unionidae) to a record drought in the Gulf Coastal Plain of southwestern Georgia. Journal of North American Benthological Society, 23, 494-506.

Gum, B., Lange, M., \& Geist, J. (2011). A critical reflection on the success of rearing and culturing juvenile freshwater mussels with a focus on the endangered freshwater pearl mussel (Margaritifera margaritifera L.). Aquatic Conservation: Marine and Freshwater Ecosystems, 21, 743-751.

Haag, W. R., \& Warren, M. L. (2008). Effects of severe drought on freshwater mussel assemblages. Transactions of the American Fisheries Society, 137, 1165-1178.

IPCC (2014). Climate change 2014: Synthesis report. Contribution of working groups I, II and III to the fifth assessment report of the Intergovernmental Panel on Climate Change. In R. K. Pachauri, \& L. A. Meyer (Eds.). Geneva, Switzerland: IPCC.

IPMA (2017). Instituto Português do Mar e da Atmosfera. Retrieved from http://www.ipma.pt

Kemp, D. W., Oakley, C. A., Thornhill, D. J., Newcomb, L. A., Schmidt, G. W., \& Fitt, W. K. (2011). Catastrophic mortality on inshore coral reefs of the Florida Keys due to severe low-temperature stress. Global Change Biology, 17, 3468-3477.

Lake, P. S. (2011). Drought and aquatic ecosystems: Effects and responses. Oxford, UK: Wiley-Blackwell.

Lopes-Lima, M., Sousa, R., Geist, J., Aldridge, D. C., Araujo, R., Bergengren, J., ... Van Damme, D. (2017). Conservation status of freshwater mussels in Europe: state of the art and future challenges. Biological Reviews, 92, 572-607.

Magalhães, M. F., Beja, P., Schlosser, I. J., \& Collares-Pereira, M. J. (2007) Effects of multi-year droughts on fish assemblages of seasonally drying Mediterranean streams. Freshwater Biology, 52, 1494-1510.

Morales, J., Peñín, E., \& Lizana, M. (2011). Depredación ocasional de Sus scrofa L. sobre una metapoblación relíctica de Margaritifera margaritifera L. (Bivalvia: Mollusca) en el río Negro (NO de España). Galemys, 23, 51-56.

Mouthon, J., \& Daufresne, M. (2006). Effects of the 2003 heatwave and climatic warming on mollusc communities of the Saône: A large lowland river and of its two main tributaries (France). Global Change Biology, 12, 441-449.
Mouthon, J., \& Daufresne, M. (2015). Resilience of mollusc communities of the River Saone (eastern France) and its two main tributaries after the 2003 heatwave. Freshwater Biology, 60, 2571-2583.

Oliveira, J. M., Segurado, P., Santos, J. M., Teixeira, A., Ferreira, M. T., \& Cortes, R. V. (2012). Modelling stream-fish functional traits in reference conditions: Regional and local environmental correlates. PLoS One, 7(9), e45787.

Reis, J. (2003). The freshwater pearl mussel [Margaritifera margaritifera (L.)] (Unionoida: Bivalvia) rediscovered in Portugal and threats to its survival. Biological Conservation, 114, 447-452.

Santos, R. M. B., Sanches Fernandes, L. F., Varandas, S. G. P., Pereira, M. G., Sousa, R., Teixeira, A., ... Pacheco, F. A. L. (2015). Impacts of climate change and land-use scenarios on Margaritifera margaritifera, an environmental indicator and endangered species. Science of the Total Environment, 511, 477-488.

Sousa, R., Amorim, A., Froufe, E., Varandas, S., Teixeira, A., \& Lopes-Lima, M. (2015). Conservation status of the freshwater pearl mussel Margaritifera margaritifera in Portugal. Limnologica, 50, 4-10.

Sousa, R., Amorim, A., Sobral, C., Froufe, E., Varandas, S., Teixeira, A., \& Lopes-Lima, M. (2013). Ecological status of a Margaritifera margaritifera (Linnaeus, 1758) population at the southern edge of its distribution (River Paiva, Portugal). Environmental Management, 52, 1230-1238.

Sousa, R., Varandas, S., Cortes, R., Teixeira, A., Lopes-Lima, M., Machado, J., \& Guilhermino, L. (2012). Massive die-offs of freshwater bivalves as resource pulses. Annales Limnologie-International Journal of Limnology, 48, 1-8.

Varandas, S., Lopes-Lima, M., Teixeira, A., Hinzmann, M., Reis, J., Cortes, R., ... Sousa, R. (2013). Ecology of Southern European pearl mussels (Margaritifera margaritifera): First record of two new populations on the rivers Terva and Beça (Portugal). Aquatic Conservation: Marine and Freshwater Ecosystems, 23, 374-389.

Walters, A. D., \& Ford, N. B. (2013). Impact of drought on predation of a state-threatened mussel, Potamilus amphichaenus. The Southwestern Naturalist, 58, 479-481.

Wernberg, T., Bennett, S., Babcock, R. C., de Bettignies, T., Cure, K., Depczynski, M., ... Harvey, E. S. (2016). Climate-driven regime shift of a temperate marine ecosystem. Science, 353, 169-172.

\section{SUPPORTING INFORMATION}

Additional supporting information may be found online in the Supporting Information section at the end of the article.

How to cite this article: Sousa R, Ferreira A, Carvalho F, Lopes-Lima M, Varandas S, Teixeira A. Die-offs of the endangered pearl mussel Margaritifera margaritifera during an extreme drought. Aquatic Conserv: Mar Freshw Ecosyst. 2018;28:1244-1248. https://doi.org/10.1002/aqc.2945 